\title{
Cassava Pulp Enzymatic Hydrolysate as a Promising Feedstock for Ethanol Production
}

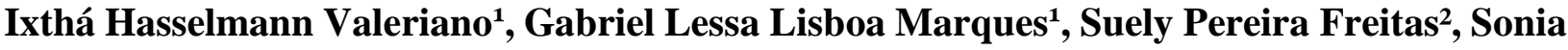 \\ Couri $^{1}$, Edmar das Mercês Penha ${ }^{3}$, Márcia Monteiro Machado Gonçalves ${ }^{*}$ \\ ${ }^{1}$ Universidade do Estado do Rio de Janeiro - Departamento de Tecnologia de Processos Bioquímicos, Rio de Janeiro, \\ Rio de Janeiro, Brazil; ${ }^{2}$ Universidade Federal do Rio de Janeiro - Escola de Química, Rio de Janeiro, Rio de Janeiro, \\ Brazil; ${ }^{3}$ Embrapa - Agroindústria de Alimentos Rio de Janeiro, Rio de Janeiro Brazil
}

\begin{abstract}
The aim of this study was to produce bioethanol from enzymatic hydrolysates of cassava pulp, a by-product of cassava flour manufacturing, using an alcohol-tolerant Saccharomyces cerevisiae strain. First, the best operational condition of the starch hydrolysis process was determined through a complete factorial design $\left(2^{4}\right)$, with triplicates at the central point. The independent variables evaluated were: the concentrations of $\alpha$-amylase (Termamyl $2 X)$ and glucoamylase (AMG 300L) and both liquefaction and saccharification times. The most favorable hydrolysis condition in the assay was achieved using $0.517 \mathrm{~mL}$ AMG.g starch ${ }^{-1}$ and $0.270 \mathrm{~mL}$ Termamyl.g starch ${ }^{-1}$, with liquefaction and saccharification times of 1 and $2 \mathrm{~h}$, respectively. The broth obtained at this hydrolysis condition contained a high glucose concentration (160 g. $\left.\mathrm{L}^{-1}\right)$. Once the best reaction conditions were determined, fermentation tests were carried out in a 3 L bioreactor, in a batch system, at $30{ }^{\circ} \mathrm{C}, 100 \mathrm{rpm}$ and pH 5.5, using $3 \mathrm{~g} . \mathrm{L}^{-1}$ (dry biomass) of yeast as inoculum. After $24 \mathrm{~h}$ of fermentation, an ethanol concentration of $68 \mathrm{~g} . \mathrm{L}^{-1}$ was obtained, with 0.48 ethanol yield and $2.83 \mathrm{~g} . \mathrm{L}^{-1} \cdot \mathrm{h}^{-1}$ productivity. These results indicate the potential use of cassava pulp, a by-product of cassava flour industries in Brazil, as a raw material for bioethanol production.
\end{abstract}

Keywords: Starch waste, Enzymatic hydrolysis, Alcoholic fermentation

\footnotetext{
* Author for correspondence: marciamg@uerj.br
} 


\section{INTRODUCTION}

In Brazil, majority of the fuel ethanol is produced by the fermentation of sugarcane. However, other raw materials such as agro-industrial waste rich in cellulosic fibers and starch might be used as well. The use of waste for ethanol generation can stabilize the price of biofuels compared to gasoline and reduce the potential environmental impacts associated with them. An agro-industrial waste, quite abundant and little explored to this end is the solid by-product of cassava starch and flour processing (cassava bagasse or pulp), which has a large amount of starch. Cassava (Manihot esculenta spp. esculenta) is a root crop with a high starch content of up to $90 \%$ (dry weight) and grows well on infertile land with minimal input of chemicals, such as fertilizers, herbicides and insecticides, making it one of the cheapest and most sustainable agro-based feedstocks ${ }^{1}$. Cassava is native to South America and has been probably taken to other continents by Europeans after the colonization of America ${ }^{2}$. Cassava shows a high tolerance to drought and infertile soils and presents the highest production of starch per hectare in the world, because of which cassava cultivation is practiced in the less developed countries $^{3}$. It is mainly cultivated by smallscale farmers in Africa, Latin America, and Asia, with a total farming area of over 18 million hectares ${ }^{1}$. Among the countries that cultivate cassava, Brazil ranks the second place (with $7.7 \%$ of world production) after Nigeria $(19.5 \%)^{3}$. Cassava can be classified into bitter or brava (toxic) and sweet or mansa (cyanide free), according to the concentration of its cyanide content, a harmful substance to the human health. In general, the bitter is used industrially whereas the sweet is used in the homemade food. Generally, for each ton of processed cassava, an average of $150 \mathrm{~kg}$ of cassava pulp (dry basis) and $6 \mathrm{~kg}$ of bark are produced. These solid wastes are often discarded at landfill sites without any form of treatment, which raises concerns about its disposal in the environment ${ }^{4}$. Cassava pulp contains approximately $40-70 \%$ starch that cannot be physically extracted and $11.5 \%$ fibers ${ }^{5}$. Thus, at a time of sustainable development, the use of agro-industrial waste rich in polysaccharides, which are not fermentable directly, has been a potential alternative to produce ethanol from an abundant and low commercial value biomass ${ }^{6}$. To recycle the high concentration of starch in the cassava pulp, the hydrolysate of this waste has been used as a substrate in microbial processes to manufacture higher value-added products ${ }^{4}$. Since there are starch manufacturers near the alcohol distillery, cassava pulp can also be used for ethanol production, mainly fine alcohol which has a specific market ${ }^{7}$. Moreover, this alcohol might be utilized to generate hydrogen for fuel cells, which in turn generates electricity. Hydrogen may become a promising energy source of the global energy matrix within a few decades, after overcoming certain technological barriers. Starch is a macromolecule which is non-fermentable by yeast, thus requires to be hydrolyzed through chemical or enzymatic processes. Enzymatic hydrolysis is the most widely used process owing to its low energy consumption, high yield, selectivity and high operating flexibility ${ }^{8}$. However, there are some limitations regarding the industrial use of enzymes, including high initial investment, enzyme cost, need of specialized professionals and sophisticated laboratories ${ }^{9,10}$. Several publications have focused on the synergic action of enzymes in the enzymatic hydrolysis processes, mainly on those involving endo- and exoamylases, such as $\alpha$-amylases and glucoamilases, $\alpha$-amylases and glucosidases, $\alpha$-amylases and maltases, amyloglucosidases and pullulanases, $\beta$-amylases and pullulanases, and other blends of commercial enzymes. Acting together, each endocatalytic event increases the number of substrate sites for exoamylases, leading to an enhanced conversion rate ${ }^{10}$. In the enzymatic conversion of starch where $\alpha$-amylase and amyloglucosidase act synergically, the key steps are liquefaction and saccharification.

During liquefaction at $90-100{ }^{\circ} \mathrm{C}, \alpha$-amylase hydrolyzes the $\alpha-(1,4)$ glycosidic bonds in the starch, leading to the rapid reduction of the gel viscosity and the production of 
maltodextrins which are further saccharified by amyloglucosidase, generating a variety of sugars ${ }^{11}$. Saccharomyces cerevisiae does not produce $\alpha$-amylase and glucoamylase, the necessary enzymes to hydrolyze starch, thus hydrolysis of the substrate is required before the alcoholic fermentation ${ }^{9}$. Production of ethanol from starch can be carried out by means of two processes, namely, separate hydrolysis and fermentation (SHF) or simultaneous saccharification and fermentation (SSF) ${ }^{12}$. In SSF, the simultaneous addition of amylolytic enzymes and microorganisms hinders the establishment of ideal conditions for the alcohol production. Therefore, the main advantage of a separate process (SHF) is the possibility of working with optimized conditions in the both enzymatic hydrolysis and the fermentation steps ${ }^{12}$. The aim of this study was to establish the appropriate conditions for the enzymatic hydrolysis of starch from cassava pulp and the production of ethanol from this hydrolysate using an alcohol-tolerant strain of yeast Saccharomyces cerevisiae Hansen BY4741, in order to determine a condition that provides higher yields.

\section{MATERIALS AND METHODS}

\section{Materials}

Cassava pulp (CP) was provided by Halotek-Fadel Industrial Ltda, Palmital, Brazil and was used after being crushed in a hammer mill. The analysis of two batches of cassava pulp with $10.1 \%$ moisture content showed the following average composition: $54.4 \%$ $\left(\mathrm{w} . \mathrm{w}^{-1}\right)$ starch, $1.65 \%\left(\mathrm{w} \cdot \mathrm{w}^{-1}\right)$ ash, $1.55 \%\left(\mathrm{w} \cdot \mathrm{w}^{-1}\right)$ protein and $0.16 \%\left(\mathrm{w} \cdot \mathrm{w}^{-1}\right)$ fatty matter. The two enzymes used in this study were kindly provided by Novozymes. The Termamyl $2 \mathrm{X}$ used in the liquefaction is a thermostable $\alpha$-amylase produced by Bacillus licheniformis with optimum $\mathrm{pH}$ and temperature of 6-8 and $90-105^{\circ} \mathrm{C}$, respectively. In the saccharification process, AMG 300L (Amyloglucosidase) was used which was produced by a strain of Aspergillus niger with an optimum $\mathrm{pH}$ and temperature of 4-4.5 and $58-60{ }^{\circ} \mathrm{C}$, respectively. The microorganism used was an alcohol-tolerant strain of Saccharomyces cerevisiae Hansen BY4741, obtained from the Chemistry Institute of the Federal University of Rio de Janeiro (Universidade Federal do Rio de Janeiro UFRJ).

\section{Enzymatic hydrolysis experiments using complete factorial design}

The starch hydrolysis process was determined through a complete factorial design $\left(2^{4}\right)$, with triplicates at the central point. The selected independent variables were the concentration of the enzymes $\alpha$-amylase (Termamyl 2X) and glucoamylase (AMG $300 \mathrm{~L}$ ) and the liquefaction and saccharification times. Each variable was evaluated at two different levels listed in Table 1. Statistical analysis of the experimental data was performed by the Statistica software, with $95 \%$ confidence $^{13}$.

Table 1 Actual and coded values used in complete factorial design $\left(2^{4}\right)$ of hydrolysis reactions

\begin{tabular}{ccccc}
\hline \multirow{2}{*}{ Factor } & \multicolumn{2}{c}{$1^{\text {st }}$ phase-Liquefaction $\left(100{ }^{\circ} \mathrm{C}\right)$} & \multicolumn{2}{c}{$2^{\text {nd }}$ phase-Saccharification $\left(60{ }^{\circ} \mathrm{C}\right)$} \\
\cline { 2 - 5 } Level & $\begin{array}{c}\text { A: }[\text { Termamyl] } \\
\left.(\mathrm{mL} \cdot \mathrm{g} \mathrm{starch})^{-1}\right)\end{array}$ & $\begin{array}{c}\text { B: Liquefaction time } \\
(\mathrm{h})\end{array}$ & $\begin{array}{l}\mathrm{C}:[\mathrm{AMG}] \\
\left(\mathrm{mL} \cdot \mathrm{g} \mathrm{starch}{ }^{-1}\right)\end{array}$ & $\begin{array}{c}\text { D: Saccharification time } \\
(\mathrm{h})\end{array}$ \\
\hline-1 & 0.270 & 1 & 0.110 & 2 \\
0 & 0.477 & 2 & 0.313 & 3 \\
1 & 0.683 & 3 & 0.517 & 4 \\
\hline
\end{tabular}


The hydrolysis experiments were performed in $250 \mathrm{~mL}$ Erlenmeyer flasks containing $30 \mathrm{~g} \mathrm{CP}$ with the solid:liquid ratio of 1:3. The flasks were heated for 15 minutes at 120 ${ }^{\circ} \mathrm{C}$ to improve the availability of the starch macromolecules (amylose and amylopectin) for the enzymatic action. In the liquefaction phase, the pretreated $\mathrm{CP}$ was mixed with an enzyme solution of Termamyl 2x (0.270 to $\left.0.683 \mathrm{~mL} . \mathrm{g} \mathrm{starch}{ }^{-1}\right)$ and maintained at 100 ${ }^{\circ} \mathrm{C}$ for 1,2 and $3 \mathrm{~h}$. This mixture was then acclimatized at $60{ }^{\circ} \mathrm{C}$ and saccharified by AMG 300L ( 0.110 to $\left.0.517 \mathrm{~mL} . \mathrm{g} \mathrm{starch}{ }^{-1}\right)$ for 2,3 and $4 \mathrm{~h}$. The CP hydrolysates were filtered to remove unhydrolyzed starch and other fibrous materials.

\section{Ethanol fermentation in bioreactor}

The strain was cultivated on YEDP (Yeast Extract Dextrose Peptone) agar slants and incubated for $72 \mathrm{~h}$ at $32{ }^{\circ} \mathrm{C}$. The slants were then kept in a refrigerator at $4{ }^{\circ} \mathrm{C}$. The inoculum was grown in Erlenmeyer flask containing $100 \mathrm{~mL}$ YEDP medium at $30^{\circ} \mathrm{C}$ with continuous shaking at $100 \mathrm{rpm}$ for $12 \mathrm{~h}$, centrifuged ( $3000 \mathrm{rpm}$ for $15 \mathrm{~min}$ ) and finally standardized to 3 g... - $^{-1}$ Cassava pulp hydrolysate was frozen to avoid gelatinization of the starch and the possible contamination. The fermentation broth was prepared using $1 \mathrm{~L}$ of hydrolysate enriched with yeast extract (1\%) and meat peptone (1\%), added with Tween 80 as an antifoaming agent at a concentration of $0.05 \%$. Fermentation studies were carried out in a bioreactor (Biostat A Plus-Sartorius) using a $3.0 \mathrm{~L}$ vessel (working volume of $1.0 \mathrm{~L}$ ) equipped with $\mathrm{pH}$, temperature, and agitation controls. The bioreactor was operated in a batch system under agitation rate of $100 \mathrm{rpm}$, at $30{ }^{\circ} \mathrm{C}$ and $\mathrm{pH}$ of 5.5 controlled by addition of $2 \mathrm{M} \mathrm{NaOH}$ or $1 \mathrm{M} \mathrm{H}_{2} \mathrm{SO}_{4}$. After inoculation, fermentation process lasted up to $24 \mathrm{~h}$ and samples were withdrawn every two hours to measure cell, glucose, and ethanol concentrations.

\section{Determination of concentration of cells, substrate, and product}

Cell growth was estimated by measuring optical density of the culture at $570 \mathrm{~nm}$ $\left(\mathrm{OD}_{570}\right)$. The results were used to generate yeast growth curves, from which dry cell weight (DCW) was estimated in the culture solution. A good linear relationship was obtained between DCW and $\mathrm{OD}_{570}$. The DNS (dinitrosalicylic acid) method ${ }^{14}$ was used for the determination of total reducing sugar (TRS) and starch content after acid hydrolysis ${ }^{12}$. Glucose and ethanol were analyzed by High-Performance Liquid Chromatography (HPLC) using Waters Chromatographic system equipped with W600 pump and Biorad HPX 87C column (300 $\mathrm{mm} \times 7.8 \mathrm{~mm}$ ), and were detected based on 2014 refractive index. The column was maintained at $80^{\circ} \mathrm{C}$ and samples were eluted by Milli-Q water at a flow rate of $0.6 \mathrm{~mL} \cdot \mathrm{min}^{-1}$. All samples were filtered through a membrane (pore size $=0.22 \mu \mathrm{m}$ ) connected to a vacuum filtration system. Quantification of ethanol and glucose was done by comparison with external standards.

\section{RESULTS AND DISCUSSIONS}

\section{Hydrolysis of Cassava Pulp}

The starch content obtained in this study was $54.4 \%$ w.w ${ }^{-1}$, a value similar to that $(50 \%$ w. $\left.\mathrm{w}^{-1}\right)$ reported by Kosugi et al. ${ }^{15}$. Based on this value, these authors considered cassava pulp to be a competitive and potential source of raw material for ethanol production compared to the dried cassava root. Moreover, these values are similar to those reported by Saito and Cabello ${ }^{16}$ who analyzed the same material used in this study. The best experimental conditions for $\mathrm{CP}$ enzymatic hydrolysis were selected through the 
complete factorial experimental design $\left(2^{4}\right)$, using the concentration of total reducing sugars as the dependent variable (Table 2).

Table 2 Complete factorial design $\left(2^{4}\right)$ of four independent variables with three center points showing the actual and coded values along with the dependent variable (total reducing sugars-TRS).

\begin{tabular}{|c|c|c|c|c|c|c|c|c|c|}
\hline \multirow{2}{*}{ Essay } & \multicolumn{4}{|c|}{ Codified variable } & \multicolumn{4}{|c|}{ Actual variable } & \multirow{2}{*}{$\begin{array}{c}\begin{array}{c}\text { Dependent } \\
\text { variable }\end{array} \\
\text { TRS } \\
\left(\mathrm{g} \cdot \mathrm{L}^{-1}\right)\end{array}$} \\
\hline & A & B & $\mathrm{C}$ & $\mathrm{D}$ & $\begin{array}{c}{[\text { Termamyl] }} \\
\left(\mathrm{mL} \cdot \mathrm{g}^{-1} \mathrm{starch}\right)\end{array}$ & $\begin{array}{l}\text { Liquefaction } \\
\text { time (h) }\end{array}$ & $\begin{array}{l}{[\mathrm{AMG}]} \\
\left(\mathrm{mL} \cdot \mathrm{g}^{-1}\right. \\
\text { starch })\end{array}$ & $\begin{array}{l}\text { Saccharification } \\
\text { time (h) }\end{array}$ & \\
\hline 1 & -1 & -1 & -1 & -1 & 0.270 & 1 & 0.110 & 2 & 165.7 \\
\hline 2 & 1 & -1 & -1 & -1 & 0.683 & 1 & 0.110 & 2 & 169.4 \\
\hline 3 & -1 & 1 & -1 & -1 & 0.270 & 3 & 0.110 & 2 & 146.0 \\
\hline 4 & 1 & 1 & -1 & -1 & 0.683 & 3 & 0.110 & 2 & 165.3 \\
\hline 5 & -1 & -1 & 1 & -1 & 0.270 & 1 & 0.517 & 2 & 186.5 \\
\hline 6 & 1 & -1 & 1 & -1 & 0.683 & 1 & 0.517 & 2 & 192.4 \\
\hline 7 & -1 & 1 & 1 & -1 & 0.270 & 3 & 0.517 & 2 & 156.0 \\
\hline 8 & 1 & 1 & 1 & -1 & 0.683 & 3 & 0.517 & 2 & 182.0 \\
\hline 9 & -1 & -1 & -1 & 1 & 0.270 & 1 & 0.110 & 4 & 167.2 \\
\hline 10 & 1 & -1 & -1 & 1 & 0.683 & 1 & 0.110 & 4 & 183.5 \\
\hline 11 & -1 & 1 & -1 & 1 & 0.270 & 3 & 0.110 & 4 & 152.7 \\
\hline 12 & 1 & 1 & -1 & 1 & 0.683 & 3 & 0.110 & 4 & 170.1 \\
\hline 13 & -1 & -1 & 1 & 1 & 0.270 & 1 & 0.517 & 4 & 182.0 \\
\hline 14 & 1 & -1 & 1 & 1 & 0.683 & 1 & 0.517 & 4 & 183.5 \\
\hline 15 & -1 & 1 & 1 & 1 & 0.270 & 3 & 0.517 & 4 & 177.2 \\
\hline 16 & 1 & 1 & 1 & 1 & 0.683 & 3 & 0.517 & 4 & 192.1 \\
\hline 17 & 0 & 0 & 0 & 0 & 0.477 & 2 & 0.313 & 3 & 179.8 \\
\hline 18 & 0 & 0 & 0 & 0 & 0.477 & 2 & 0.313 & 3 & 173.5 \\
\hline 19 & 0 & 0 & 0 & 0 & 0.477 & 2 & 0.313 & 3 & 170.1 \\
\hline
\end{tabular}

The lowest sugar content was obtained in the tests 3,7 and 11 which have a lower enzyme concentration in common in the liquefaction step. Indeed, the estimation of the effects of the independent variables on the concentration of total reducing sugars indicated that TRS was significantly influenced by the concentration of the enzymes $\alpha$ amylase (Termamyl 2X) and glucoamylase (AMG 300L) as well as the liquefaction time, as shown in the Pareto chart (Fig. 1a). The surface response showed that TRS increased linearly with the concentration of enzymes (Fig. 1b) in the selected experimental conditions. The ANOVA data with $95 \%$ confidence interval $(\mathrm{p}<0.05)$ are presented in table 3 . The statistical parameters $\mathrm{F}_{\text {calculated }} / \mathrm{F}_{\text {tabulated }}$ ratio was higher than 1, thus, the mathematical model with significant coefficients $(p<0.5)$ can be described by the fitted model.

Table 3 ANOVA for enzymatic hydrolysis evaluation.

\begin{tabular}{lcccccc}
\hline Source of variation & Sum of Squares & $\mathrm{df}$ & Mean Square & Fcalculated & Ftabulated & $\mathrm{p}$ \\
\hline CTermamyl & 689.1 & 1 & 689.1 & 18.77 & 4.41 & 0.0025 \\
tliquefation & 492.8 & 1 & 492.8 & 13.43 & & 0.0064 \\
CAmyloglucosidase & 1085.7 & 1 & 1085.7 & 29.58 & 0.0006 \\
Residual & 293.6 & 8 & 36.7 & & & \\
Total SS & 2972.8 & 18 & & & & \\
\hline
\end{tabular}

df- degree of freedom 


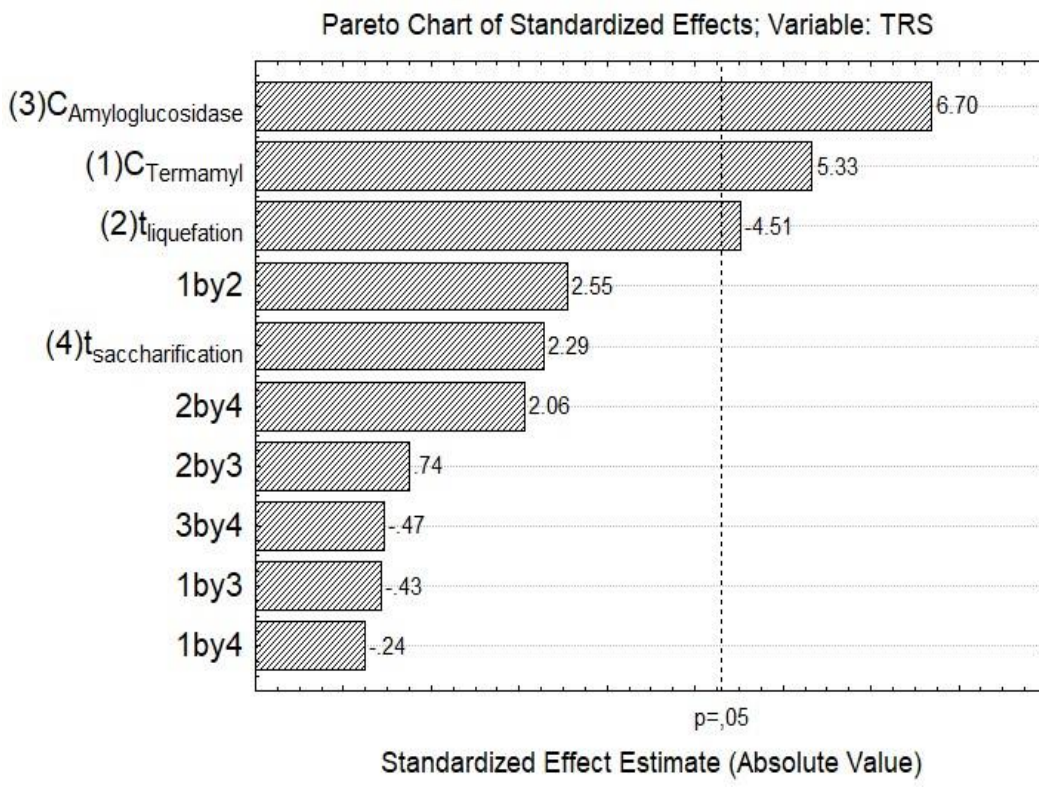

(a)
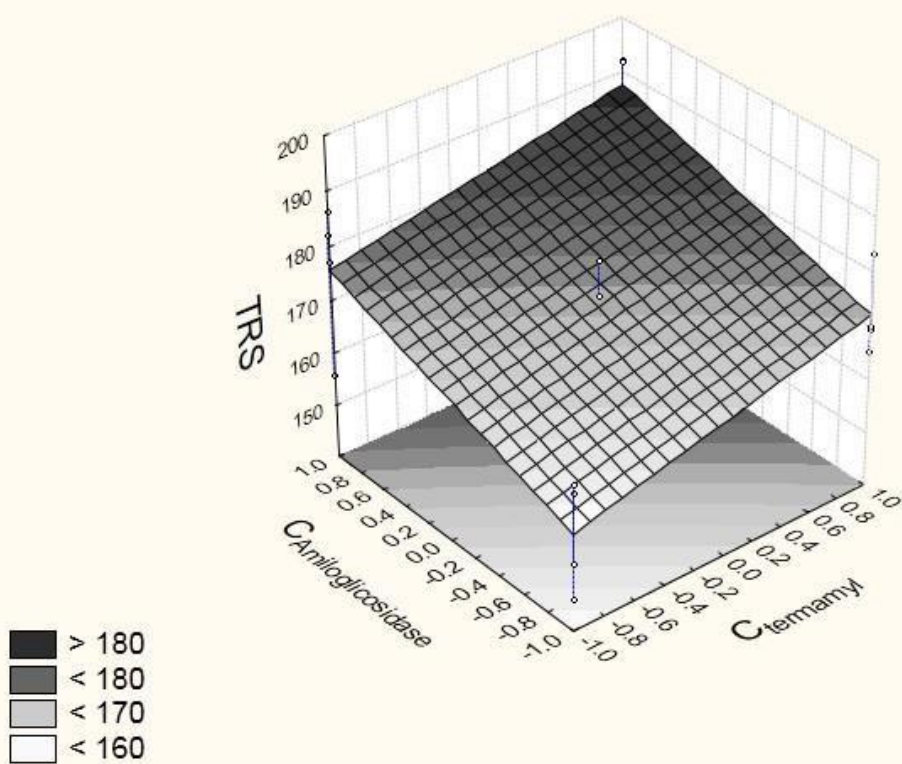

(b)

Figure 1 (a) Pareto chart of standardized effects for cassava pulp enzymatic hydrolysis for the $2^{4}$ full factorial design. The point at which the effect estimates were statistically significant (at $p \leq 0.05$ ) is indicated by the broken vertical line. (b) Response surface showing the effect of enzyme concentrations. Dependent variable: concentration of TRS (g.L $\left.\mathrm{L}^{-1}\right)$.

The highest concentration of reducing sugars (192.4 TRS g.L $\left.\mathrm{L}^{-1}\right)$ was obtained when the enzyme concentrations were highest (assay 6). However, by taking into account the high cost of enzymes, the assay condition 5 which yielded 186.5 g.L $\mathrm{L}^{-1}$ TRS was selected. The concentration of AMG was maintained at its maximum level $\left(0.517 \mathrm{~mL} \mathrm{AMG.g}^{-1} \mathrm{starch}\right)$ whereas the other parameters were set at their lowest levels $\left(0.270 \mathrm{~mL}\right.$ Termamyl.g ${ }^{-1}$ starch, $1 \mathrm{~h}$ of liquefaction and $2 \mathrm{~h}$ of saccharification). In the enzymatic hydrolysis, besides the high cost of enzyme, a high amount of energy can be consumed when the reaction takes several hours or days. The lowest liquefaction and saccharification times adopted in this study ( 1 and $2 \mathrm{~h}$ respectively) decreased the incubation time at high temperatures. Under assay condition 5, the yield of total reducing sugar obtained was $560 \mathrm{mg} \cdot \mathrm{g}^{-1}$ of cassava pulp and $1029 \mathrm{mg} \cdot \mathrm{g}^{-1}$ of starch. On the other hand, Virunanon et al. ${ }^{17}$ tried to reduce the hydrolysis process reaction time of cassava pulp and obtained 
the highest level of released reducing sugar $\left(514.3 \mathrm{mg} \cdot \mathrm{g}^{-1}\right.$ starch) by simultaneous liquefaction and saccharification with a mixture of Liquozyme-SC DS, Spirizyme Fuel and Novozyme NS 50012 enzyme, incubated at $\mathrm{pH} \mathrm{4.5,50}{ }^{\circ} \mathrm{C}$ for $24 \mathrm{~h}$. The yield obtained in this study (1029 mg.g ${ }^{-1}$ starch) was far greater than that obtained by Virunamon et al. ${ }^{17}$, however, in this study, two-step CP liquefaction and saccharification process was performed using two other enzymes (Termamyl $2 \mathrm{X}$ and AMG 300L). Once the essay 5 was selected, cassava pulp $(600 \mathrm{~g})$ was hydrolyzed producing $170 \mathrm{~g} . \mathrm{L}^{-1} \mathrm{TRS}$, the equivalent of 160 g.L $\mathrm{L}^{-1}$ glucose (HPLC). Moreover, according to Curvelo-Santana et al. ${ }^{18}$, an enzymatic hydrolysis efficiency of $79.4 \%$ was estimated, which was achieved merely within $1 \mathrm{~h}$ of liquefaction and $2 \mathrm{~h}$ of saccharification.

\section{Alcoholic fermentation}

Figure 2 shows the mean of four experiments for ethanol production, cell growth and substrate consumption during 24 hours of fermentation.

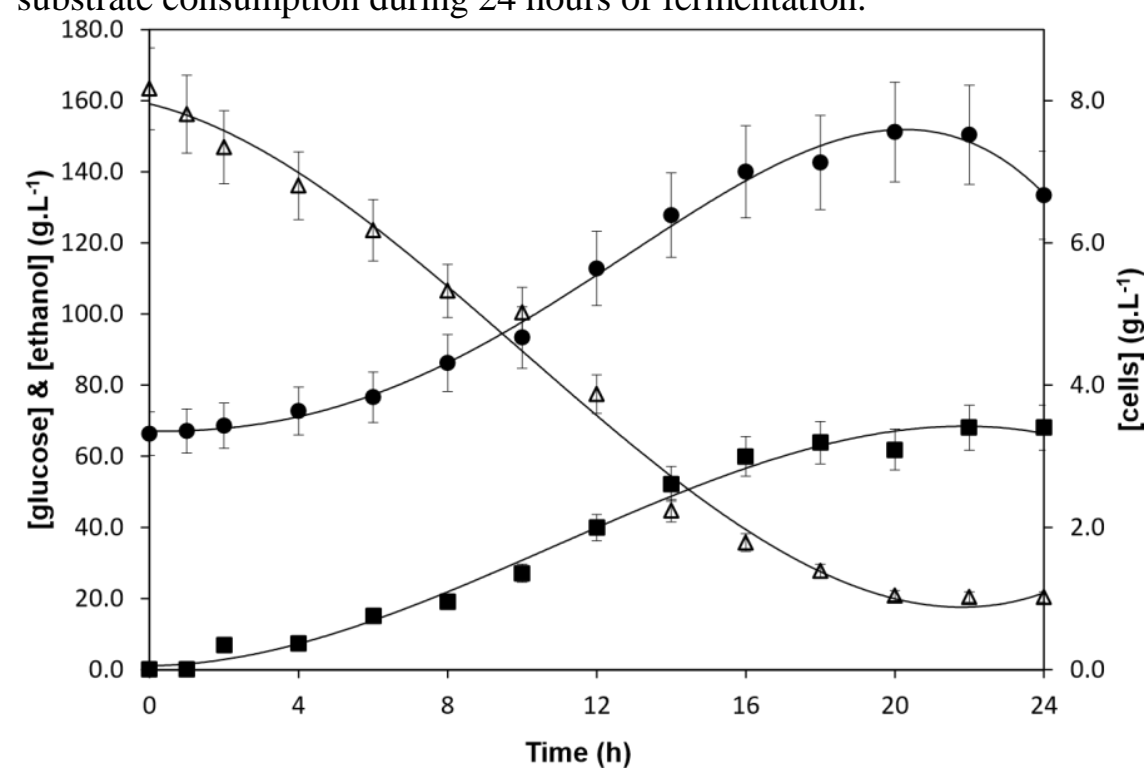

Figure 2 Kinetics of alcoholic fermentation using cassava pulp hydrolysates containing $16 \%$ glucose. Ethanol production $(\boldsymbol{\bullet})$, cell growth $(\bullet)$ and substrate consumption $(\Delta)$. The bar represents the percentage error.

As shown in the cellular growth curve (Fig. 2), the adaptation phase of yeast to the cassava pulp hydrolysates was about 3 to $4 \mathrm{~h}$. Moreover, in the exponential growth phase, the maximum specific growth rate $\left(\mu_{\max }=0.07 \mathrm{~h}^{-1}\right)$ was achieved within the range of 8 to $16 \mathrm{~h}$. This value was lower than the ones reported by Kasavi et al. ${ }^{19}$ for starch molasses using different industrial strains of $S$. cerevisiae ranging from 0.33 a $0.39 \mathrm{~h}^{-1}$. These results remark the need of yeast adaptation to fermentation broth containing high sugar concentration (18\%), after hydrolysis of cassava pulp. In addition, figure 2 shows that the glucose was not completely consumed $\left(S_{\mathrm{f}}=20.4 \mathrm{~g} . \mathrm{L}^{-1}\right)$ after $24 \mathrm{~h}$ of fermentation and ethanol production reached 68.0 g.L $\mathrm{L}^{-1}$, which is $8.6 \%\left(\mathrm{v} . \mathrm{v}^{-1}\right)$. Therefore, it was not possible to observe the yeast inhibition by ethanol. However, assuming that inhibition of Hansen BY4741 yeast is attained only by alcohol concentrations above $10 \%\left(\mathrm{v} \cdot \mathrm{v}^{-1}\right)$, initial glucose concentrations in the medium should be above 180 g.L. ${ }^{-1}$, and the fermentation should be carried out for at least $45 \mathrm{~h}$. According to this argument, the fermentation of cassava pulp hydrolysates by $S$. cerevisiae Hansen BY4741 has similarities with the fermentation of corn, in which fermentation time of 48-72 $\mathrm{h}$ is normally required to obtain $10-12 \%\left({\left.\mathrm{v} . \mathrm{v}^{-1}\right)}^{-}\right.$ethanol $^{20,21}$. However, this approximate 2 to 
2.5 fold increase in fermentation time does not promote an increased ethanol production at the same ratio. Table 4 compares the results of this study to those from other three studies carried out under similar conditions using agro-industrial waste hydrolysates of cassava and corn meal. In all cases fermentation was carried out as a batch process, using media containing fermentable sugars and strains of $S$. cerevisiae.

Table 4 Comparison of the fermentation results of this study with those of the previous reports.

\begin{tabular}{|c|c|c|c|c|}
\hline Parameters & This study & Shah et al. ${ }^{22}$ & $\begin{array}{l}\text { Curvelo-Santana } \\
\text { et al. }{ }^{18}\end{array}$ & Nikolic et al. ${ }^{23}$ \\
\hline Material & $\begin{array}{l}\text { cassava pulp } \\
\text { hydrolysates }\end{array}$ & $\begin{array}{l}\text { starch industry } \\
\text { waste hydrolysates }\end{array}$ & $\begin{array}{l}\text { cassava root } \\
\text { hydrolysates }\end{array}$ & $\begin{array}{l}\text { corn meal } \\
\text { hydrolysates }\end{array}$ \\
\hline Starch content $(\%)$ & $54.40\left(\mathrm{w} . \mathrm{w}^{-1}\right)$ & - & 71.65 (dry weight) & $76.75\left(\mathrm{w} \cdot \mathrm{w}^{-1}\right)$ \\
\hline Substrate & $16 \%$ glucose & $15 \% \mathrm{RS}$ & $\begin{array}{l}\sim 6.5 \% \text { RS }+10 \\
\text { g.L } \mathrm{L}^{-1} \text { sucrose }\end{array}$ & $15 \%$ glucose \\
\hline Microorganism & $\begin{array}{l}\text { S. cerevisiae } \\
\text { Hansen BY4741 }\end{array}$ & $\begin{array}{l}\text { Thermo-tolerant } S \text {. } \\
\text { cerevisiae }\end{array}$ & Saccharomyces & $\begin{array}{l}\text { S. cerevisiae } \\
\text { var. ellipsoideus }\end{array}$ \\
\hline Inoculum & $3 \mathrm{~g} . \mathrm{L}^{-1}\left(\sim 1.5 \% \mathrm{v} \cdot \mathrm{v}^{-1}\right)$ & $10 \%\left(\mathrm{v} \cdot \mathrm{v}^{-1}\right)$ & - & $2 \%\left(\mathrm{v} \cdot \mathrm{v}^{-1}\right)$ \\
\hline $\mathrm{t}_{\mathrm{f}}(\mathrm{h})$ & 24 & 72 & 120 & 26 \\
\hline Ethanol (g.L $\left.\mathrm{L}^{-1}\right)$ & 68 & 74 & $29.3 * *$ & $52.8 * *$ \\
\hline $\mathrm{Y}_{\mathrm{P} / \mathrm{S}}$ & 0.48 & 0.47 & 0.45 & 0.35 \\
\hline$\underset{\mathrm{P}}{\mathrm{Q}}\left(\mathrm{g} \cdot \mathrm{L}^{-1} \cdot \mathrm{h}^{-1}\right)^{*}$ & 2.83 & $1.03 *$ & $0.24 *$ & 2.03 \\
\hline
\end{tabular}

The values of kinetic parameters obtained in this study were higher than those reported in the previous studies (Table 4) ${ }^{18,22,23}$, and ethanol yield $\left(\mathrm{Y}_{\mathrm{P} / \mathrm{S}}\right)$ and productivity $\left(\mathrm{Q}_{\mathrm{p}}\right)$ were 0.48 and $2.83 \mathrm{~g} . \mathrm{L}^{-1} \cdot \mathrm{h}^{-1}$, respectively, after $24 \mathrm{~h}$. However, in the fermentation of starch industry waste hydrolysates containing $15 \%$ reducing sugars ${ }^{22}$ gave rise to slightly higher alcohol concentration, probably because of the amount of the inoculum used $\left(10 \% \mathrm{v} \cdot \mathrm{v}^{-1}\right)$. It is noteworthy that the fermentation time in this study was the lowest among all. Therefore, the results of this investigation indicate that cassava pulp is a potential feedstock for ethanol production like other classic starchy sources. In Brazil, the greatest starch manufacturers that have the potential to produce this waste on a large scale are concentrated in the South-Central and Southeastern regions. Owing to this situation, micro-distilleries can be constructed near these sources of residual raw materials in order to reduce their cost of transportation.

\section{CONCLUSION}

This study clearly showed that a high yield ethanol production from cassava pulp can be carried out in two stages, namely separate hydrolysis and fermentation (SHF). In the hydrolysis of cassava pulp, the AMG concentration was the most significant factor. A high yield of total reducing sugars (TRS) were obtained with reduced liquefaction and saccharification times, decreasing the requirement of high incubation temperatures. Suitable conditions for obtaining enzymatic hydrolysates of cassava pulp were 0.517 mL AMG. ${ }^{-1}$ starch, $0.270 \mathrm{~mL}$ Termamyl. $\mathrm{g}^{-1}$ starch, $1 \mathrm{~h}$ of liquefaction and $2 \mathrm{~h}$ of saccharification. In batch culture studies of cassava pulp hydrolysate, Saccharomyces cerevisiae Hansen BY4741 showed tolerance to an ethanol concentration of 68 g.L $\mathrm{L}^{-1}$ $\left(8.6 \% \mathrm{v} \cdot \mathrm{v}^{-1}\right)$ obtained after $24 \mathrm{~h}$ of fermentation. The kinetic parameter values of 0.48 
ethanol yield and $2.83 \mathrm{~g} \cdot \mathrm{L}^{-1} \cdot \mathrm{h}^{-1}$ ethanol productivity showed that this process can be a good alternative for alcohol production. Furthermore, the use of solid waste from flour processing (cassava pulp) may reduce the potential environmental impacts associated to it.

\section{ACKNOWLEDGEMENTS}

The authors are grateful to CAPES for granting a scholarship to the first author and to FAPERJ for financial support.

\section{REFERENCES}

1. Zhang M, Xie L, Yin Z, Khanal SK, Zhou Q. Biorefinery approach for cassava-based industrial wastes: Current status and opportunities. Bioresource Technol. 2016; 215: 50-62.

2. Demiate IM, Kotovicz V. Cassava starch in the Brazilian food industry. Ciênc. Tecnol. Aliment. 2011; 31(2): 388-397.

3. GROXKO, M. Análise da conjuntura Agropecuária-Mandioca Safra 2014-2015. Boletim do Departamento de Economia Rural, Secretaria de Estado e do Abastecimento. Available on: http://www.agricultura.pr.gov.br/arquivos/File/deral/Prognosticos/mandioca_2014_15.pdf.

Accessed 05/19/2016.

4. Pandey A, Soccol CR, Nigam P, Soccol VT, Vandenberghe LPS, Mohan R. Biotechnological potential of agroindustrial residues. II: cassava bagasse. Bioresource Technol. 2000; 74(1): 81-87.

5. Nigam PS Nee', Pandey A. Biotechnology for Agro-Industrial Residues Utilisation: Utilisation of Agro-Residues. Houten: Springer Science \& Business Media; 2009.

6. Bringhenti L, Cabello C, Urbano LH. Fermentação alcoólica de substrato amiláceo hidrolisado enriquecido com melaço de cana. Ciênc. Agrotec. 2007; 31(2): 429-432.

7. Leonel M, Cereda MP. Melhoria do rendimento de hidrólise enzimática para produção de etanol a partir de farelo de mandioca. Braz. J. Food Technol. 1999; 2(1-2): 111-118.

8. Zanin GM, Santana CC, Bon EP, Giordano RC, Moraes FF, Andrietta SR, et al. Brazilian bioethanol program. Appl. Biochem. Biotech. 2000; 84-86(1-9): 1147-1161.

9. Hashem M, Darwish SMI. Production of bioethanol and associated by-products from potato starch residue stream by Saccharomyces cerevisiae. Biomass Bioenerg. 2010; 34(7): 953-959.

10. Robertson GH, Wong DWS, Lee CC, Wagschal K, Smith MR, Orts WJ. Native or raw starch digestion: A key step in energy efficient biorefining of grain. J. Agr. Food Chem. 2006; 54(2): 353-365.

11. Sadeghi A, Shahidi F, Mortazavi SA, Mahalati MN. Evaluation of different parameters effect on maltodextrin production by $\alpha$-amylase Termamyl 2-x. World Appl. Sci. J. 2008; 3(1): 34-39.

12. Santos JRA, Souto-Maior AM, Gouveia ER, Martín C. Comparação entre processos em SHF e em SSF de bagaço de cana-de-açúcar para a produção de etanol por Saccharomyces cerevisiae. Quim. Nova 2010; 33(4): 904-908.

13. Montgomery DC, Runger GC. Applied Statistics and Probability for Engineers, $6^{\text {th }}$ ed. New Jersey: John Willey \& Sons; 2014.

14. Miller GL. Use of dinitrosalicylic acid reagent for determination of reducing sugar. Anal. Chem. 1959; 31(3): 426-428.

15. Kosugi A, Kondo A, Ueda M, Murata Y, Vaithanomsat P, Thanapase W, et al. Production of ethanol from cassava pulp via fermentation with a surface engineered yeast strain displaying glucoamylase. Renew. Energ. 2009; 34(5): 1354-1358.

16. Saito IM, Cabello C. Produção de etanol a partir de hidrolisado obtido por tratamento hidrotérmico de farelo de mandioca. Energ. Agric. 2006; 21(3): 34-44.

17. Virunanon C, Ouephanit C, Burapatana V, Chulalaksananukul W. Cassava pulp enzymatic hydrolysis process as a preliminary step in bio-alcohols production from waste starchy resources. J. Cleaner Prod. 2013; 39: 273-279.

18. Curvelo-Santana JC, Ehrhardt DD, Tambourgi EB. Otimização da produção de álcool de mandioca. Ciênc. Tecnol. Aliment. 2010; 30(3): 613-617. 
19. Kasavi C, Finore I, Lama L, Nicolaus B, Oliver SG, Oner ET, et al. Evaluation of industrial Saccharomyces cerevisiae strains for ethanol production from biomass. Biomass Bioenerg. 2012; 45: 230-238.

20. Bai FW, Anderson WA, Moo-Young M. Ethanol fermentation technologies from sugar and starch feedstocks. Biotechnol. Adv. 2008; 26(1): 89-105.

21. Bothast RJ, Schlicher MA. Biotechnological processes for conversion of corn into ethanol. Appl. Microbiol. Biot. 2005; 67: 19-25.

22. Shah FA, Aziz S, Memon HR, Rajoka MI. Ethanol production kinetics by a thermo-tolerant mutant of Saccharomyces cerevisiae from starch industry waste (Hydrol). Pak. J. Anal. Environ. Chem. 2010; 11(1): 16-21.

23. Nikolic S, Mojovic L, Pejin D, Rakin M, Vukasinovic M. Production of bioethanol from corn meal hydrolyzates by free and immobilized cells of Saccharomyces cerevisiae var. ellipsoideus. Biomass Bioenerg. 2010; 34(10): 1449-1456. 